\title{
First synthesis of the economic costs of biological invasions in Japan
}

\author{
Yuya Watari', Hirotaka Komine ${ }^{1,2}$, Elena Angulo ${ }^{3}$, \\ Christophe Diagne ${ }^{3}$, Liliana Ballesteros-Mejia ${ }^{3}$, Franck Courchamp ${ }^{3}$
}

I Forestry and Forest Products Research Institute, 1 Matsunosato, Tsukuba-shi, Ibaraki 305-8687, Japan 2 present adress: Faculty of Agriculture, Yamagata University, 1-23 Wakaba-machi, Tsuruoka, Yamagata, 997-0037 Japan 3 Université Paris-Saclay, CNRS, AgroParisTech, Ecologie Systématique Evolution, 91405, Orsay, France

Corresponding author: Yuya Watari (ywatari@affrc.go.jp)

Academic editor:E. García-Berthou | Received 30 September 2020 | Accepted 29 January 2021 | Published 29 July 2021

Citation: Watari Y, Komine H, Angulo E, Diagne C, Ballesteros-Mejia L, Courchamp F (2021) First synthesis of the economic costs of biological invasions in Japan. In: Zenni RD, McDermott S, García-Berthou E, Essl F (Eds) The economic costs of biological invasions around the world. NeoBiota 67: 79-101. https://doi.org/10.3897/neobiota.67.59186

\begin{abstract}
Despite the large body of knowledge recognising the impact of biological invasions on biodiversity, their economic impact has been less evaluated. However, the associated economic costs ought to provide useful information on many different aspects to prevent and manage invasions. Here, we describe the economic costs of biological invasions in Japan using InvaCost, a recently-published global database on monetary costs extracted from English and non-English sources, as well as a complementary search, thereby filling a gap in regional knowledge. We focused on the following four dimensions when analysing the economic costs of biological invasions: damage to biodiversity, damage to human livelihood, management for biodiversity and management for human livelihood. Interestingly, there was no information about biological invasion costs for Japan in English, but the Japanese search and our additional survey provided a total of 630 cost entries, with a total economic cost of 728 million USD (2017 value, equivalent to 62 billion JPY). These entries appeared in 33 documents and corresponded to a total of 54 species. We showed that: 1) damage costs from biological invasions tend not to be assessed as frequently as management costs and are more underestimated; 2) despite the numerous entries, an overwhelmingly limited amount of the management budget was allocated to biodiversity conservation compared to protecting human livelihood; 3) budgets have been intensively invested in invasive species management on small islands, which reflects the vulnerability of small island ecosystems and economies to biological invasions; 4) the recorded costs still seem to be greatly underestimated, mainly due to the lack of recording (and potentially limited access to recorded cost information). These findings are not only specific to Japan, but may also be widely applicable to most other countries. The future recording of economic costs will help to close the gap between actual and recorded costs, leading to more realistic guidelines for tackling biological invasions.
\end{abstract}

Copyright Yuya Watari et al. This is an open access article distributed under the terms of the Creative Commons Attribution License (CC BY 4.0), which permits unrestricted use, distribution, and reproduction in any medium, provided the original author and source are credited. 


\begin{abstract}
Japanese
日本における外来種の侵入が引き起こす経済的コストの初統合. 外来種の侵入が引き起こす生 物多様性への影響については, 多くの知見がある一方で, その経済的影響はあまり評価されて いない. しかし, 外来種の侵入が関連する経済的コストを評価することは, 侵入の阻止, 管理の ための様々な側面から役立つ情報を提供してくれるはずである.ここでは, 最近公開された英語 情報源および英語以外の情報源から抽出した経済コストに関するグローバルなデータベースで あるInvaCostを用いて, 日本における外来種の侵入の経済的コス卜を記載するとともに, グロー バルデータベースと地域的な知見のギャップを埋めるために, 補完的な検索も行った. 外来種の 侵入の経済的コストを分析する際には,生物多様性への被害, 人間の生活への被害, 生物多様 性のための管理, 人間の生活のための管理の $4 つ の$ 次元に注目した. 興味深いことに, 日本の外 来種の侵入のコストに関する情報は英語の情報源には存在しなかったが, 日本語検索による情 報源と本研究の追加調査により, 合計630件のコスト情報件数が得られ, 合計で7億2800万米 ドル (2017年の価值, 620億円相当)の経済コストが計上された.これらのエントリは33のデー タソースに記載され, コストが記録された外来種は合計 54 種であった. 本研究では以下のことを 示した. 1)外来種の侵入による被害コストは管理コストに比べて評価されることが少なく, 過小 評価される傾向があること, 2)外来種管理の予算のうち, 生物多様性の保全のための対策は多 数の項目があるにもかかわらず, 人間生活を守るための予算と比べると額が圧倒的に少ないこ と,3)離島の外来種対策に集中的に予算が投入されており,これは離島の生態系や経済が外来 種の侵入に脆弱であることを反映していること, 4)コストは多くの場合記録されていなかったり アクセスが困難であったりするために, 今回計上されたコストは依然として大幅に過小評価され ているように思われること.これらの知見は日本だけでなく, 他の多くの国にも広く適用可能であ る. 今後, 経済的コストを記録することで, 実際のコストと計上されるコストのギャップを埋めるこ とができ, 外来種の侵入に対応するためのより現実的なガイドラインにつながると考えられる.
\end{abstract}

\title{
Abstract in French
}

Première synthèse du coût économique des invasions biologiques au Japon. Malgré le vaste cortège de connaissances qui reconnaît l'impact des invasions biologiques sur la biodiversité, leur impact économique a été moins évalué. Pourtant, les coûts économiques associés sont sensés constituer des informations utiles pour bien des aspects de prévention et de gestion des invasions biologiques. Dans cette étude, nous décrivons le coût économique des bioinvasions au Japon en utilisant d'une part InvaCost, une base de données globale récemment publiée sur les coûts monétaires des invasions et extraites à partir de sources rédigées en langues anglaise et non-anglaises, et d'autre part des recherches complémentaires plus spécifiques, comblant ainsi des lacunes de connaissance régionale. Notre analyse des coûts économiques des invasions biologiques est déclinée selon les quatre dimensions suivantes : les dégâts sur la biodiversité, les dégâts sur les moyens humains de subsistance, la gestion de la biodiversité et la gestion des moyens humains de subsistance. De façon intéressante, il n'y a aucune information concernant le coût des invasions biologiques au Japon qui soit disponible en anglais, mais une recherche en Japonais et nos investigations complémentaires ont permis de compiler 630 mentions de coûts, pour un total de 728 millions USD (valeur de 2017, équivalents à 62 milliards yens). Ces mentions ont été identifiées à partir de 33 documents et correspondent à 54 espèces. Nous montrons que: 1) les coûts des dégâts liés aux invasions biologiques ont tendance à ne pas être évalués aussi fréquemment que les coûts liés à leur gestion, et sont davantage sous-estimés ; 2) malgré les nombreuses mentions, le budget alloué à la conservation de la biodiversité est étonnamment faible comparé à celui alloué pour préserver les moyens humains de subsistance ; 3) des budgets ont été massivement investis dans la gestion des espèces envahissantes sur les petites îles, ce qui reflète la vulnérabilité de ces écosystèmes et économies insulaires face aux invasions biologiques ; 4) les coûts mentionnés semblent largement sous-estimés, essentiellement à cause du manque de documentation rapportant ces coûts (et potentiellement d'un accès limité aux informations sur les coûts rapportés). Ces résultats ne sont 
pas spécifiques au Japon, mais pourraient aussi être largement applicables à la plupart des autres pays. De futurs efforts sur l'estimation et la documentation des coûts économiques permettra de combler l'écart entre les coûts réels et les coûts effectivement enregistrés, ce qui mènera à des recommandations plus réalistes pour lutter contre les invasions biologiques.

\section{Abstract in Spanish}

Primera síntesis de los costos económicos de las invasiones biológicas en Japón. A pesar de la gran cantidad de información científica sobre las invasiones biológicas que reconoce los impactos en la biodiversidad, los impactos económicos han sido menos evaluados. Sin embargo, los costos económicos asociados a las invasiones deberían proporcionar información útil en muchos aspectos, para prevenir y gestionar las invasiones. En este trabajo, describimos los costos económicos de las invasiones biológicas en Japón, usando la recientemente publicada base de datos InvaCost, que contiene los costes económicos extraídos a partir de documentos en lengua inglesa y en otras lenguas no inglesas, así como datos obtenidos en una búsqueda complementaria, lo cual ha llenado una laguna del conocimiento regional. Enfocamos el análisis de los costos económicos de las invasiones biológicas en las siguientes cuatro dimensiones: los daños a la biodiversidad, los daños al bienestar humano, la gestión para la biodiversidad y la gestión para el bienestar humano. Es de destacar que no hubo información en inglés para Japón, mientras que nuestra búsqueda adicional resultó en 630 entradas de costos, con un total económico de 728 millones de dólares americanos (valor de 2017, equivalente a 62 mil millones de yenes). Estas entradas de costos procedieron de 33 documentos y correspondieron a un total de 54 especies. Mostramos que: 1) los daños de las invasiones biológicas parecen no haber sido evaluados tan frecuentemente como las estrategias de gestión y por lo tanto parecen más subestimados; 2) a pesar de las numerosas entradas, la cantidad de dinero de gestión asignada a biodiversidad fue abrumadoramente limitada en comparación con la asignada al bienestar humano; 3) el dinero se ha invertido de forma intensiva en el manejo de las especies invasoras en islas pequeñas, lo que refleja la vulnerabilidad de los ecosistemas de las islas pequeñas y sus economías a las invasiones biológicas; 4) los costos reportados parecen estar aún fuertemente subestimados, debido sobre todo a la falta de registros (y por un acceso a la información sobre costos potencialmente limitado). Estos resultados no son específicos de Japón, sino que pueden ser aplicados ampliamente a la mayor parte de los países. Si en el futuro se registran los costes económicos, esto ayudará a cerrar la brecha que existe entre los costes que ocurren y los reportados, lo cual llevará a proponer medidas más realistas para abordar las invasiones biológicas.

\section{Keywords}

Actual costs, biodiversity, island, InvaCost, invasive species, Japanese, non-English language, underestimated costs

\section{Introduction}

Biological invasions are known to be a leading cause of biodiversity degradation worldwide (Clavero and Garcia-Berthou 2005; Bellard et al. 2016). However, their economic impacts and costs on several sectors, such as the environment, agriculture and fishery, as well as the economic expenses associated with their management, have been less evaluated (Courchamp et al. 2017). The economic evaluation of invasive species may provide useful information at many levels (Dana et al. 2013). For example, it may contribute to raising awareness about the threat posed by invasive species. In addi- 
tion, prioritising management actions and assessing their cost-effectiveness can help to improve local strategies towards invaders. Up to now, there have been some economic assessments for regions like the United States (Pimentel et al. 2005), Europe (Kettunen et al. 2008) and Southeast Asia (Nghiem et al. 2013). However, regional coverage is lacking and the overview of the economic costs is still unknown (but see Diagne et al. 2020a, 2021; Angulo et al. 2021), indicating the necessity for further research to evaluate the economic costs in many countries and regions. In particular, comprehensive estimates at the national level - the most important unit for designing and implementing management - are in dire need.

Japan has the third largest GDP (International Monetary Fund 2018) in the world, with the fourth largest international trade market (World Trade Statistical Review 2019) and a large pet trade (Auliya et al. 2016; Kitade and Naruse 2020). As a result, Japan is a world centre of both biological invasions and invasion science (Mito and Uesugi 2004; Mizutani and Goka 2010). Although the Global Invasive Species Database (2020) lists 263 invasive species for Japan, the Ecological Society of Japan identified 2,230 species in its list of alien species for the country almost 20 years ago (Ecological Society of Japan 2002). Amongst these species, many invasive species are known to induce severe ecological impacts and agricultural damage. Examples of ecological impacts include predation on endangered species by invasive predators, such as the small Indian mongoose Urva auropunctata (Watari et al. 2008), the black rat Rattus rattus (Chiba 2010), free-ranging cats Felis silvestris catus (Shionosaki et al. 2015; Kobayashi et al. 2019; Maeda et al. 2019; Azumi et al. 2021) and the green anole Anolis carolinensis (Abe et al. 2008). Examples of agricultural damage include damage to agricultural products by common raccoons Procyon lotor (Suzuki and Ikeda 2019) and alien invasive insects (Kiritani 1998). In addition, the management of invasive alien species is conducted across the country, with several large-scale projects, such as an eradication project on islands (Kiritani 1998; Koyama et al. 2004; Fukasawa et al. 2013a; Watari et al. 2013; Komine et al. 2016; Sato 2019; Yagihashi et al. 2021).

Japan features more than 6,800 islands (Higuchi and Primack 2009) with a wide geographical expanse ranging $3,000 \mathrm{~km}$ in both east-west and north-south directions (Fig. 1) and its climate ranges from subarctic to temperate and subtropical (Higuchi and Primack 2009; Japan Meteorological Agency 2016). Therefore, various invasive species in Japan are expected to incur a wide range of costs, although the comprehensive assessment of these economic costs has yet to be conducted. Such an assessment could enable us to estimate the optimal budget size and distribution for targeted management, promote biosecurity policies to prevent future potential costs and assess the cost performance of management strategies. According to the global definition of an island, the entire Japanese territory is an island. However, most Japanese people distinguish between the four largest islands (Honshu, Hokkaido, Kyushu and Shikoku) as the mainland (hereafter, mainland) and the other thousands of smaller islands as islands (hereafter, islands) (Fig. 1). This classification is mainly based on the discontinuous nature of the area (the smallest mainland is Shikoku measuring $18,298 \mathrm{~km}^{2}$, while the largest island used in this study is Okinawa-jima Island measuring 1,207 $\mathrm{km}^{2}$ ) and it features differences in most biogeographical aspects. For example, all four 


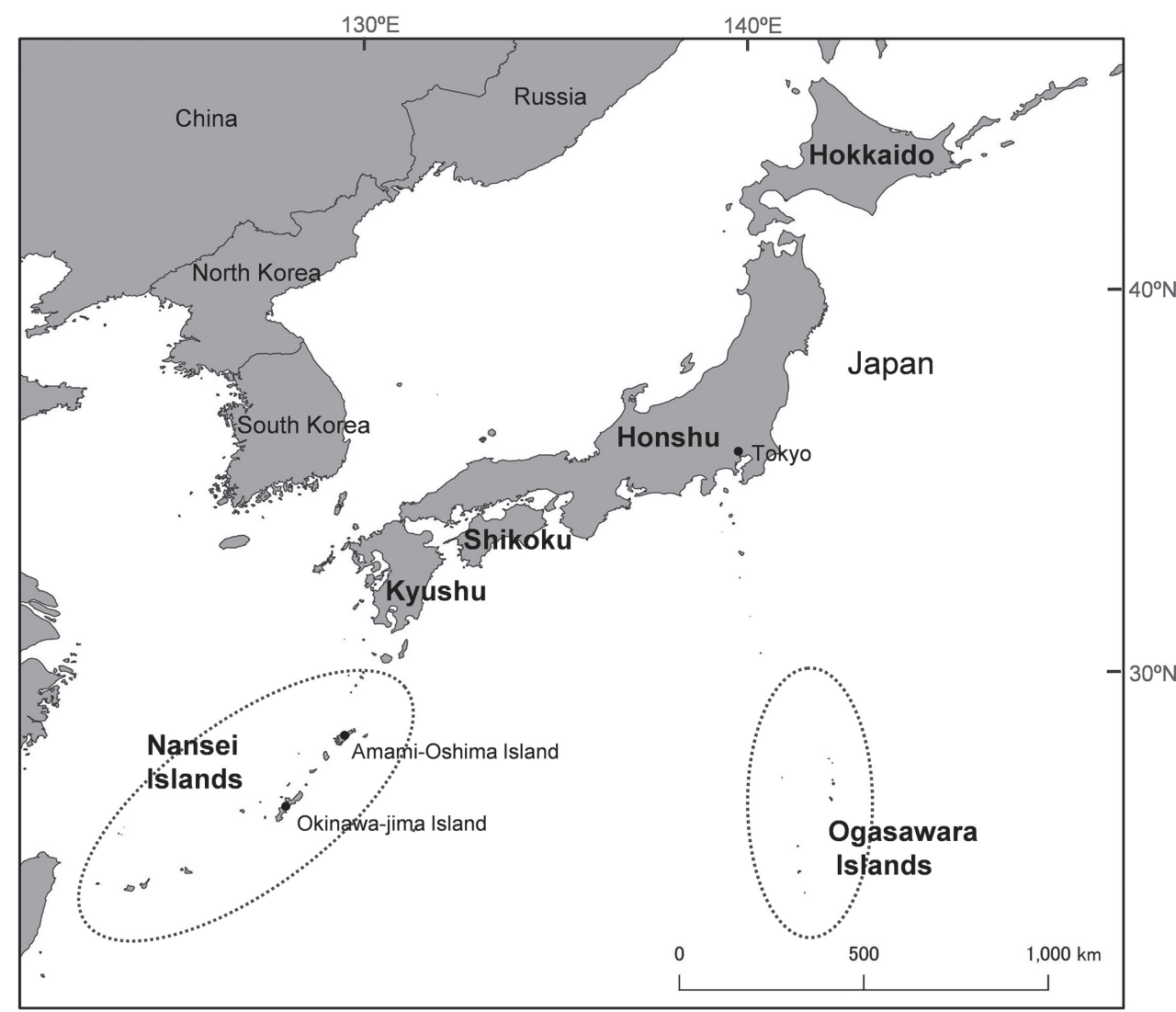

Figure I. Map of the four main islands (mainland: Hokkaido, Honshu, Shikoku, Kyushu) and Nansei Islands and Ogasawara Islands in Japan.

mainlands have multiple native mammalian carnivore species, whereas they are absent from most islands (Ohdachi et al. 2015), which, instead, have very unique and vulnerable ecosystems, where the impact of invasive species tends to be greater (Courchamp et al. 2003). Across the Japanese territory, high conservation priority has been given to the islands isolated from both the Japanese mainland and the Eurasian continent (Glen and Hoshino 2020), as they harbour many endemic and endangered species and are therefore a major component of biodiversity in Japan. For example, the Ogasawara Islands have been designated as a Natural World Heritage Site (UNESCO World Heritage Centre 2012) and part of the Nansei Islands is a candidate for a Natural World Heritage Site (UNESCO World Heritage Centre 2016). Many of these islands are extremely vulnerable to alien predators, because their native species have evolved in the absence of native predatory mammals. Therefore, assessing the economic costs of biological invasions in these regions can contribute to improving the measures to protect their valuable biodiversity. However, this has not yet been done.

A recently-published database of the economic costs of biological invasions (Angulo et al. 2020, 2021; Diagne et al. 2020b) provides comprehensive information on 
the economic damage and expenditure associated with invasive species around the world, with an extension that focuses on the entries of economic costs in non-Englishspeaking countries. Using this database and the results of a complementary search performed for this study, we aimed to describe the outline and details of the recorded economic costs of biological invasions for Japan. In particular, we described the economic costs of invasive species in Japan following two approaches. First, we focused on the difference between the economic damage caused by invasive species and the cost of their management. Invasive species damage represents a substantial economic loss (reactive) that requires scientific knowledge and administrative systems to evaluate the damage, whereas invasive species management is an expense (proactive) that allows us to calculate the cost incurred directly from the management budget. Consequently, the qualities of damage and management as economic costs differ from each other. Second, we differentiate between the targets of each type of damage and management, i.e. between human livelihood (e.g. agricultural productions and human health) and biodiversity. The impact of invasive species on human livelihood is clearly visible and can be easily monetised. Therefore, their management appears to be relatively straightforward to implement (Nuńez and Pauchard 2010; Rose et al. 2018). By contrast, the impacts on biodiversity can have a profound effect on human life in the long term (Rose et al. 2018), but the impacts on human livelihood are indirect, less visible and, hence, difficult to monetise (Courchamp et al. 2017). Therefore, expenses associated with the management of biodiversity conservation probably require increased public awareness of the value of biodiversity and the economic margins involved (Nuñez and Pauchard 2010; Rose et al. 2018). Clarifying the gaps between damage and management costs and between human production and biodiversity will help us to better understand the current situation and challenges in Japan. Ultimately, this would provide us with clues about how to better tackle the problem of invasive species in the future. Based on this framework, we further describe economic costs with a focus on: 1) the differences in taxonomic groups of the reported costs, 2) annual trends in the reported costs and 3) difference in costs between the mainland and islands. Finally, we explore the problems of data accessibility encountered during the compiling of the Japanese entries, consider the possible underestimation of the recorded costs and point out the importance of recording costs in an accessible form.

\section{Methods}

\section{Data acquisition and categorisation}

To analyse the economic cost of biological invasions in Japan, we used InvaCost (version 3.0, openly available at https://doi.org/10.6084/m9.figshare.12668570), a recently-compiled database which compiles the monetary impacts of invasive species reported in English and non-English documents worldwide (Diagne et al. 2020b; Angulo et al. 2021). InvaCost was developed following a systematic and standardised methodology 
to collect information from scientific articles, grey literature, stakeholders and expert elicitation. The most up-to-date version (v3.0) of InvaCost contains 9,823 cost entries; each entry refers to a unique cost value with specific descriptors (columns) that describe the spatial and temporal information of the cost, the taxonomy of the species causing the cost, the typology of the cost and the document reporting the cost. A set of columns reports the cost value in both local currencies and in USD, i.e. converted by dividing the cost estimate by the official market exchange rate corresponding to the year of the cost estimation and then to 2017 USD using inflation factors (Diagne et al. 2020b).

Given the importance of the search in Japanese, we summarise here how this search was performed (for more details, see Angulo et al. 2021). First, in the Web of Knowledge, the same search strings were used as in English, i.e. a combination of terms related to the economic costs and invasive species, but setting the Language to Japanese; 64 articles were retrieved but none with costs. Second, we used a similar search string in Google Scholar with Japanese terms: 205 articles were retrieved, including eight with economic costs. Finally, in the Google search engine, the Japanese terms for "budget" AND "exotic organisms" were used, directing the search to the webpage JUDGIT! (JUDGIT! 2019), a volunteer organisation that compiles the budgets of the Japanese government, which provided most of the Japanese-language entries in InvaCost_v3.0. The search of the Japanese entries was conducted for economic costs incurred through 2017.

A total of 329 cost entries was obtained from InvaCost_v3.0. Only one source came from the English database; the remaining 328 entries were Japanese and came from the non-English database (Suppl. material 1: Table S1). However, the English cost entry, based on the description of Armstrong and Ball (2005) citing Kiritani (1998), was excluded from our analyses, because Kiritani (1998) did not present a cost description and, therefore, may be considered misquoted. Moreover, this English entry represented the cost of the eradication project of melon flies Bactrocera cucurbitae and oriental flies Bactrocera dorsalis, while the Japanese entries (Reference ID: JP_6 in Suppl. material 1: Table S1) described these costs in more detail.

We also conducted additional surveys to avoid the omission of cost data from important invasive alien species in Japan, because the searches conducted in English and non-English emphasised the uniformity of the search methods across countries, which may lead to the omission of locally-important invasive species. Thus, we conducted searches in the JUDGIT! database (JUDGIT! 2019) using the common names (in Japanese) of all species listed in the " 100 worst invasive alien species in Japan" (Ecological Society of Japan 2002) as search strings. The JUDGIT! database mostly compiles budgets since 2014 with the exception of a few in 2013. Moreover, JUDGIT! not only extracts each entry, but also shows the budget subjects in which the entries are located, which, in turn, allows us to search for other projects located in each budget subject. Using this function, we also extracted cost entries related to invasive species other than the 100 worst species. Similar to the InvaCost, the search was conducted for economic costs incurred through 2017. The cost entries obtained from this additional search 
were finally combined with the entries obtained from InvaCost_v3.0 (Suppl. material 1: Table S1).

We re-classified the type of costs associated with the entries by dividing them into two categories: "Damage" and "Management". "Damage" includes the economic loss caused by the invasive alien species and the expenses incurred to repair its impacts, while "Management" includes the expenses associated with managing invasive alien species itself, including prevention, eradication, control, research, buying equipment and environmental education to promote a better understanding of invasive species management. These two categories are then further divided into two categories: "Human" and "Biodiversity", where "Human" refers to the costs directly related to human livelihood-impacted sectors, such as agriculture, fisheries, forestry and human health. "Biodiversity" refers to the costs with respect to natural ecosystems, including the impact of invasive species on native species and ecosystem services (e.g. ecotourism). The classification scheme is shown in Suppl. material 2. Amongst the costs categorised under "Management", it is sometimes difficult to clearly determine whether the purpose of management applies to "Human" or "Biodiversity". For example, the management implemented by the Ministry of Agriculture, Forestry and Fisheries can be clearly categorised as "Human", while the management implemented by the Ministry of the Environment can be categorised as either "Biodiversity" or "Human", because the objectives stated in the law include, not only the conservation of biodiversity, but also the protection of human health. Furthermore, species that can pose a risk to human health also pose a potential and future risk to biodiversity. Therefore, in this study, for species with notable characteristics that may be harmful to human health, such as venomous insects and for which large-scale management is undertaken at the beginning of an invasion, we assumed that the government implemented the management action mainly to prevent risks to human health. In this case, we classified the management costs for such species as Management_Human (e.g. the red imported fire ant Solenopsis invicta). Based on these four categories - i.e. damage to biodiversity (Damage_Biodiversity), damage to human livelihood (hereafter, Damage_Human), management for biodiversity (Management_Biodiversity) and management for human livelihood (Management_Human), subsequent analyses were conducted focusing on the number of entries and the amount of economic costs.

\section{Data analyses}

We first compared the economic costs reported for each taxonomic group using the Class and species taxonomic classification. Second, to examine the annual change in economic costs, we plotted the costs against the year. Most of the Japanese entries are based on projects conducted by the government, in which the temporal unit of entries is the Fiscal Year (e.g. FY2017 = 2017 April -2018 March). Here, for the sake of convenience, we treated the fiscal year as the year of the beginning period $($ FY2017 $=2017)$. Some of the entries in the database described total costs over multiple years. To determine the annual costs, we used the function "expand- 
YearlyCosts" from the invacost package (Leroy et al. 2020). In this case, the total cost was divided by the number of years and converted to a cost per year. Third, to compare the costs between the mainland and islands, we compared between the entries with the 'Island' column as "Y", which corresponded to islands and those with " $\mathrm{N}$ ", which corresponded to the mainland and unspecified geographic regions (Suppl. material 1: Table S1). Finally, to compare the number of entries and the amount of economic costs per unit area for the mainland and islands, we calculated the number of entries and economic costs per unit area for the total area of the mainland (361,006 km²; Honshu, Hokkaido, Kyushu and Shikoku) and the islands $\left(16,968 \mathrm{~km}^{2}\right)$. However, caution is required, as it is possible that some of the island entries are recorded in the mainland entries due to the limited identification of the location in their information sources.

\section{Results}

We obtained a total of 630 cost entries, of which 328 were from the non-English database and 302 from the search performed for this study (there were no recorded costs in English). Based on these entries, invasive species cost a total of 728 million USD (2017 value) to the Japanese economy from 1965 to 2017. These entries came from 33 documents and 16 authors (Suppl. material 1: Table S1). The author with the most entries was JUDGIT!, with 17 data sources (budget subjects of the Japanese government), 499 entries and 86 million USD. Of this information, the budgets of the Ministry of the Environment had the largest number of entries, with 318 entries, followed by 177 entries from the Ministry of Agriculture, Forestry and Fisheries and four entries from the Ministry of Economy, Trade and Industry. In terms of economic costs, the Ministry of Agriculture, Forestry and Fisheries had the largest budget at 48 million USD, followed by the Ministry of the Environment at 37 million USD and the Ministry of Economy, Trade and Industry at 0.7 million USD. The next author with most entries was the Ministry of Agriculture, Forestry and Fisheries with two data sources, which resulted in 93 entries and corresponded to 235 million USD. These were statistics on the economic damage caused by invasive mammals and birds recorded in each area of the country since 1999. The third largest entries were taken from a report from Okinawa Prefecture amounting to 10.55 million USD, which assessed the damage caused by invasive alien species in Okinawa Prefecture; this entry had not been included in the above summary of the Ministry of Agriculture, Forestry and Fisheries. These costs were followed by the report of invasive insect eradications (JP_6 in Suppl. material 1: Table S1) with five entries, with the largest costs being 333 million USD for the eradication project of invasive insects in the Nansei Islands and Ogasawara Islands, which accounted for almost half of Japan's total costs in our dataset.

The number of entries (Fig. 2a) and the amount of economic costs (Fig. 2b) aggregated for the four categories of Damage_Biodiversity, Damage_Human, Manage- 
a) Number of entries

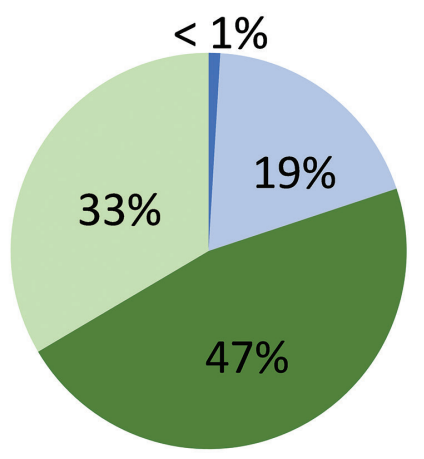

b) Cost (US\$)

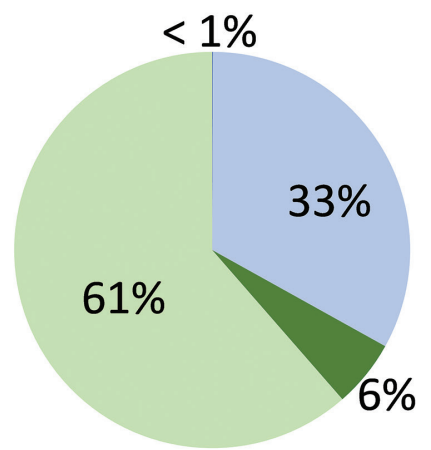

Figure 2. Breakdown of the number of cost entries (a) and the amount of costs (US\$) (b) induced by biological invasions. Damage_Biodiversity and Damage_Human represent damage caused by biological invasions to biodiversity and human livelihood, respectively. Management_Biodiversity and Management_Human represent managements for biodiversity and human livelihood, respectively.

ment_Biodiversity and Management_Human show that the largest number of entries was recorded for Management_Biodiversity, accounting for $47 \%$ of the total number of entries. However, these entries only constituted $6 \%$ of the total economic costs. By contrast, both Damage_Human and Management_Human had a high proportion of the total economic costs compared to the number of entries. Damage_Biodiversity was $<1 \%$ in both cases.

A total of 54 invasive species had reported costs (Fig. 3). As to the number of entries by taxonomic groups (Fig. 3a), mammals had the highest total number of entries (190 entries), followed by nematodes (171 entries) and insects (78 entries). The species with the highest number of entries was the pine wilt nematode Bursaphelenchus xylophilus (163 entries), which has caused widespread pine dieback in Japan. The common raccoon and small Indian mongoose both had high Damage_Human and Management_Biodiversity, whereas the Asian black hornet Vespa velutina had the second highest number of entries for Management_Human. Other species with more than 15 cost entries were the green anole Anolis carolinensis, free-ranging cats, the Argentinean ant Linepithema humile, the masked palm civet Paguma larvata, the coypu Myocastor coypus and the Taiwan squirrel Callosciurus erythraeus. Damage_Biodiversity was only recorded in the entries for the green anole, whose costs were associated with a conservation measure targeting the population of endemic insects damaged by the green anole on Ogasawara Islands (Abe et al. 2008).

For the economic cost by taxonomic groups, insects prominently had the largest amount of total costs, followed by mammals and nematodes (Fig. 3b). The costs of the other groups were relatively small. Amongst insects, the economic costs incurred by the melon fly Bactrocera cucurbitae, oriental fruit fly Bactrocera dorsalis and Sweet potato weevil Cylas formicarius were the largest, accounting for Management_Human (Fig. 3a), which corresponded to the eradication project conducted in the Nansei Is- 
a)

\section{Number of entries}

$180160140120100 \quad 80 \quad 60 \quad 40 \quad 20 \quad 0$ b)

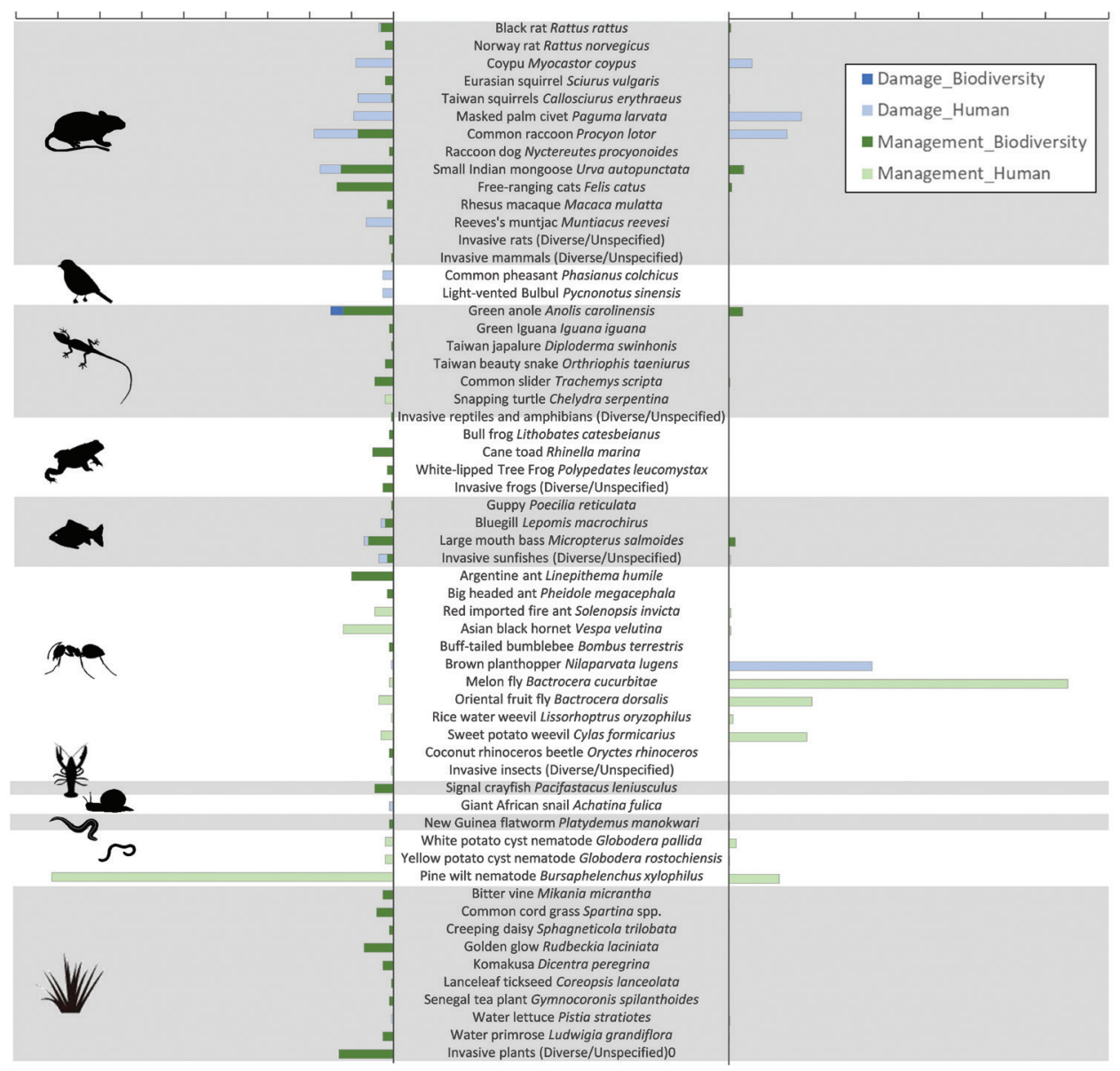

Figure 3. Taxonomic comparison of the number of cost entries (a) and the amount of cost (b) by species. Damage_Biodiversity and Damage_Human represent damage caused by biological invasions to biodiversity and human livelihood, respectively. Management_Biodiversity and Management_Human represent management for biodiversity and human livelihood, respectively. The square frames grouped, from top to bottom, into invasive mammals, birds, reptiles, amphibians, fishes, insects, crustaceans, gastropods, flatworms, nematodes and plants.

lands and Ogasawara Islands. Another invasive insect associated with large costs was the brown plant-hopper Nilaparvata lugens, which related to the emergency nationwide assessment of the economic loss in rice production after the outbreak of this species in 2013 (Ministry of Agriculture, Forestry and Fisheries 2013). By contrast, there was only a small cost associated with the Asian black hornet, even though this species had the largest number of entries. Amongst mammals, the coypu, masked-palm civet and common raccoon had relatively large costs for Damage_Human. The small In- 

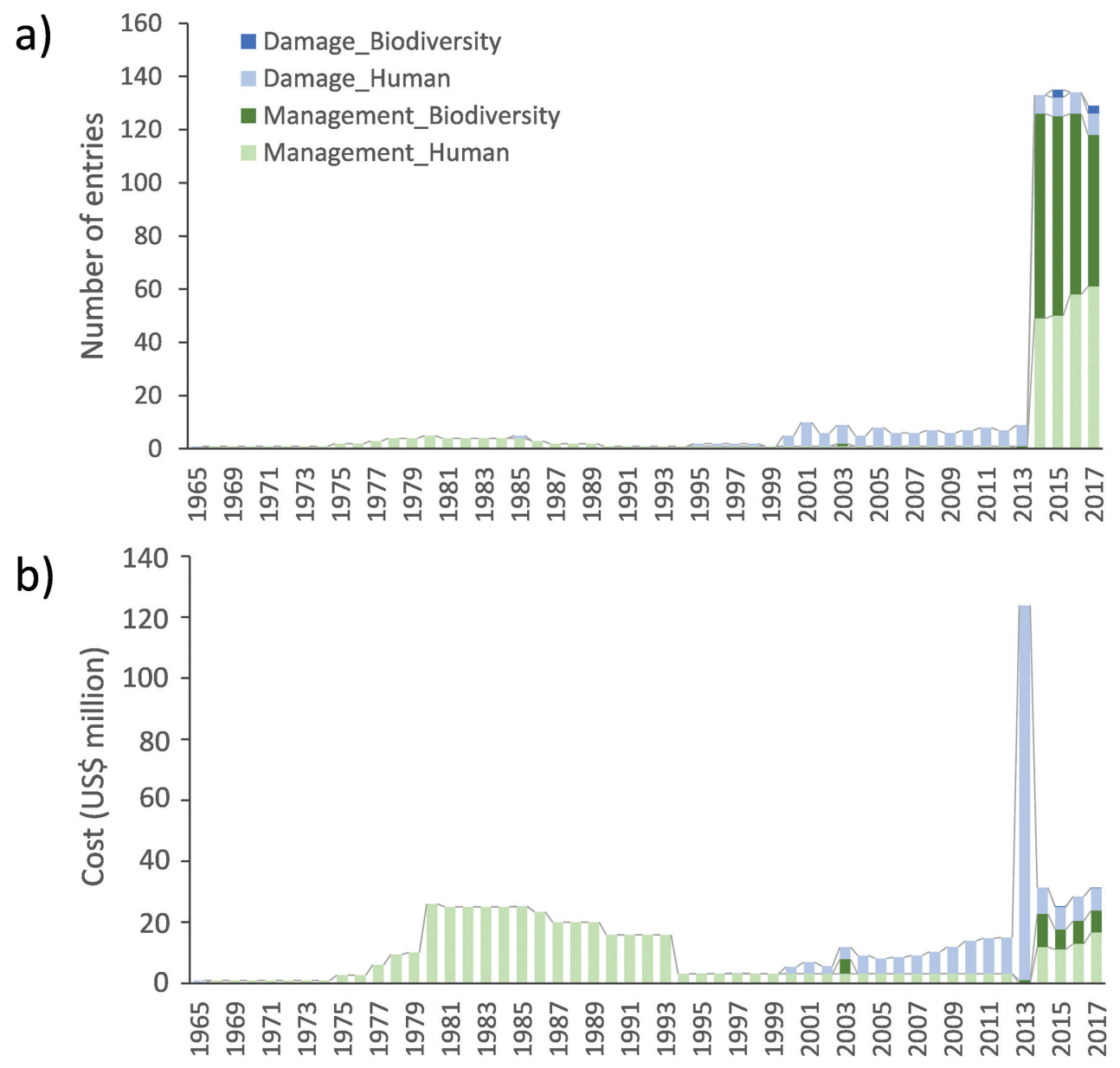

Figure 4. Annual change in the number of cost entries (a) and the amount of costs in US\$ (b). Damage_Biodiversity and Damage_Human represent damage caused by biological invasions to biodiversity and human livelihood, respectively. Management_Biodiversity and Management_Human represent management for biodiversity and human livelihood, respectively.

dian mongoose had the largest costs for Management_Biodiversity, although the values were far smaller than those associated with Damage_Human and Management_Human in other outstanding species. Amongst nematodes, the pine wilt nematode had the largest costs for Management_Human.

Annual changes in the number of expanded entries and the amount of economic costs show that the reported costs began in 1965 (Fig. 4). For the number of entries (Fig. 4a), there is a small peak from the late 1970s to the late 1990s for Management_ Human and in the early 2000s for Damage_Human. The largest peak in the number of entries has occurred since 2014, mainly in relation to Management_Biodiversity and Management_Human. By contrast, regarding the annual economic costs (Fig. 4b), the 
a)

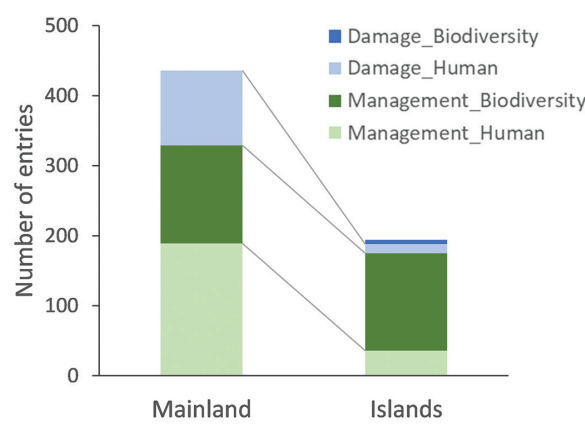

c)

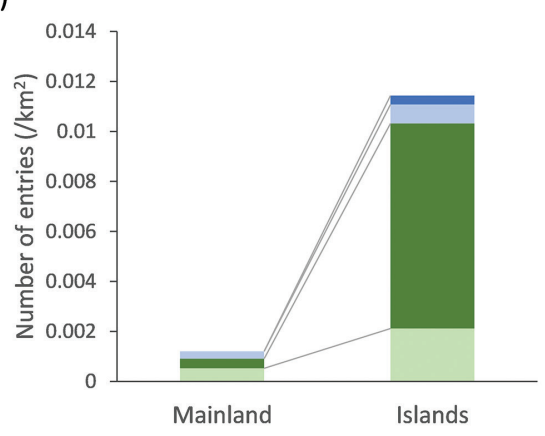

b)

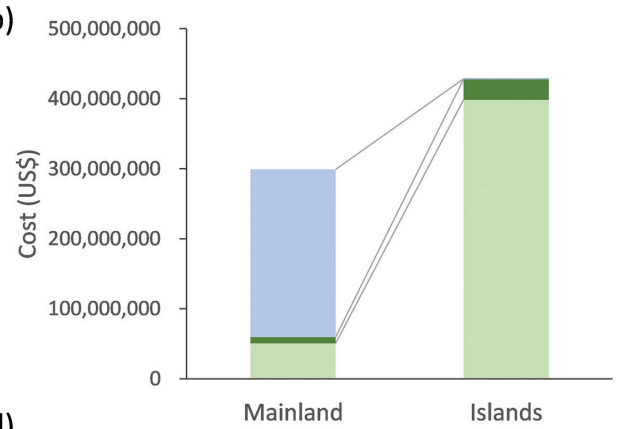

d)

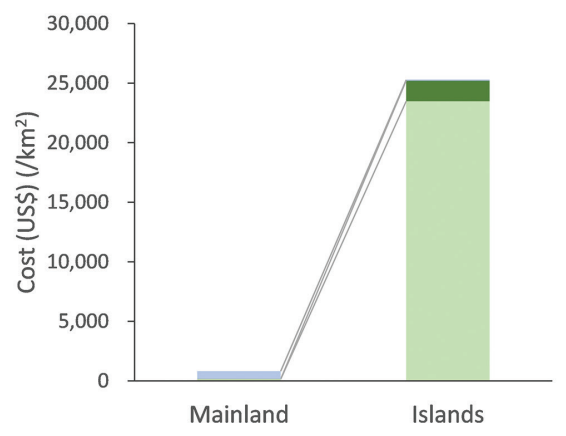

Figure 5. Comparison of (a) the mainland and islands for the number of cost entries (b) the amount of costs in US\$ (c) the number of cost entries per unit area and (d) the amount of costs per unit area. Damage_Biodiversity and Damage_Human represent damage caused by biological invasions to biodiversity and human livelihood, respectively. Management_Biodiversity and Management_Human represent management for biodiversity and human livelihood, respectively.

highest costs were recorded for Damage_Human in 2013, which corresponded to a nationwide damage assessment of a large outbreak of the brown planthopper. With the exception of this one-off assessment, high cumulative economic costs were recorded for Management_Human from the late 1970s to the early 1990s, mainly in relation to the eradication projects targeting invasive insects on islands. Since 2014, relatively high costs have been recorded by the sum of Damage_Human, Management_Biodiversity and Management_Human.

Comparing of the number of entries between the mainland and islands showed that the mainland had more reported cost entries than the islands in relation to Damage_Human and Management_Human, whereas only the cost entries for Damage_ Biodiversity were higher in the islands (Fig. 5a). By contrast, regarding the economic costs, the mainland had a higher cost for Damage_Human, although the islands exceeded the mainland in Management_Biodiversity, Management_Human and total costs (Fig. 5b), despite their smaller total land areas. The number of entries and the amount of economic costs per unit area between the mainland and islands resulted in 9.6 times more entries (Fig. 5c) and 30.5 times more costs $\left(25,285 \mathrm{USD} / \mathrm{km}^{2}\right.$; Fig. $5 \mathrm{~d}$ ) recorded for the islands. 


\section{Discussion}

\section{Summary of the major findings}

This study is the first attempt to analyse the recorded economic costs of biological invasions in Japan, which only used sources in the Japanese language: 630 cost entries with a total economic cost of 728 million USD (2017 value, equivalent to 62 billion JPY). The following are major findings in this study. First, damage costs caused by biological invasions tend not to be assessed as frequently as management costs and are more underestimated. Second, despite the numerous entries, an overwhelmingly small amount of the management budget was allocated to biodiversity conservation compared to protecting human livelihood. Third, budgets have been intensively invested in invasive species management on islands, which reflects the vulnerability of small island ecosystems and economies to biological invasions. Finally, the recorded costs seemed to be generally greatly underestimated, mainly due to the limited access to cost information.

\section{Costs associated with human livelihoods versus biodiversity}

The costs associated with human livelihoods were much higher than those associated with biodiversity. Scrutinising the nature of these costs suggests that Japan is still spending much more money on enduring or repairing damage directly related to human livelihoods rather than focusing on ecosystem conservation. In Japan, the Alien Species Act was enacted in 2005 (Mizutani and Goka 2010) and, since then, a relatively large number of projects for biodiversity conservation have been carried out, as seen in the increased number of cost entries relating to the management of invasive species for biodiversity in recent years. However, the amount of the costs allocated to these management actions for biodiversity is nevertheless very low, resulting in smaller budgets being spread across a large number of projects. This indicates that the priority for biodiversity conservation is still low in the Japanese government as a whole, except for the administrative sectors in charge of environmental conservation (e.g. Ministry of the Environment).

\section{Costs for mainland versus islands}

This study revealed that the costs per unit area were disproportionately higher on islands. As some costs incurred on islands may be reported in the costs for the mainland (see Methods), the costs reported on islands are underestimated relative to the mainland costs. To conserve native species on islands, Japan has invested a higher amount of money in managing invasive species, such as the management projects for invasive rats, goats and anole in the Ogasawara Islands (Sato 2019) and the small Indian mongoose on Amami-Oshima Island and Okinawa-jima Island (Watari 2011; Fukasawa et al. 2013b; Watari et al. 2013; Sugimura et al. 2014; Yagihashi et al. 2021), indicating the emphasis placed on the value and vulnerability of island biodiversity. In addition, 
the amount of costs for human livelihood was far higher than that for biodiversity in islands. This corresponded to the eradication projects targeting agricultural invasive insects, such as melon flies and weevils. As agriculture is a basic industry for most inhabited islands, including the production of sugarcane, sweet potatoes and fruits (e.g. Kagoshima Prefecture 2019), invasive insects could seriously damage the small and fragile economies of islands. The vulnerability of the island ecosystems and economies is thus reflected in the disproportionate cost of invasive species in islands.

\section{Potential gaps between actual costs and available data}

In general, the economic costs of biological invasions tend to be underestimated, because some are difficult to assess (e.g. costs incurred for biodiversity), even if they can exert long-term indirect impacts on humans (Nunes and van den Bergh 2001). Given the difficulty of fully filling this gap, the risk of invasive species and the necessity of their management should not only be discussed on the basis of the recorded economic costs. Another reason relates to the availability of data; if they exist, they are often difficult to access. The impacts of invasive species often occur locally and local measures tend to be implemented independently, which could prevent local practitioners and decision-makers from sharing information and technology with other regions (Kueffer et al. 2013), thus making it difficult for the scientific community to access the data. Therefore, economic assessments that only draw on the usual sources of data (i.e. scientific publications) can lead to underestimation and bias.

In this study, the overall management costs were higher than the damage costs in terms of both the number of cost entries and the amount of costs. The major difference between management and damage costs is that the former is an expense for managing biological invasions, which can be assessed by summing up the recorded budgets for human actions, whereas the latter is an economic loss caused by biological invasions, which requires a scientific approach and administrative system in order to be evaluated. For example, while management costs have been reported for many years, damage costs only began to be recorded in around 2000, when the Ministry of Agriculture, Forestry and Fisheries set up the national system to report the economic costs of crop damage by wildlife (Ministry of Agriculture, Forestry and Fisheries 2020). This correlation between recorded economic costs and research efforts implies that many costs actually incurred remain unassessed (Bradshaw et al. 2016; Kourantidou et al. 2021). In addition, it was only recently that damage to biodiversity began to be reported, although the costs recorded as damage to biodiversity in our dataset corresponded to the budget for in situ and ex situ conservation of threatened insects greatly damaged by the green anole (Karube 2019), which did not require additional efforts to evaluate the economic costs of the impact of the invasive species. This suggests that the economic costs of the invasion damage might be greatly underestimated and the degree of underestimation may be more pronounced in the case of damage to the biodiversity. Another indication of this underestimation is that only 54 species were evaluated for the economic costs out of 2,230 known to be present in Japan (Ecological Society of Japan 2002). The 
real costs, especially in terms of damage, could therefore be much higher. Although it is important to make further efforts to calculate the economic costs, it is still essential to further document the impact of invasive species on ecosystem functions, given the difficulty of adequately assessing the long-term and indirect economic losses caused by biodiversity losses (Nunes and van den Bergh 2001; Jackson 2015).

Insufficient data accessibility can also lead to underestimations. It is, therefore, a major limitation of this first synthesis of the costs of invasive species in Japan. The measures targeting invasive alien species in Japan, which are mainly based on the three laws: "Act on the Prevention of Adverse Ecological Impacts Caused by Designated Invasive Alien Species", "Protection and Control of Wild Birds and Mammals and Hunting Management Law" and "Act on Special Measures for Prevention of Damage Related to Agriculture, Forestry and Fisheries Caused by Wildlife" have been conducted at all levels of government, including the national government, 47 prefectural governments and 1,741 local municipal governments (Okabe et al. 2019). However, the entries in the dataset were biased towards those implemented by the national government, which were accessible on the internet. For example, the relatively large-scale eradication measures such as those implemented against the small Indian mongoose by the Okinawa Prefecture (Watari 2011; Yagihashi et al. 2021) and against Reeves's muntjac (Muntiacus reevesi) by Tokyo metropolitan government (Tokyo Metropolitan Government 2016) are not included in the present dataset. In addition, introduced common raccoons and masked palm civets are widespread in Japan (Ohdachi et al. 2015; Suzuki and Ikeda 2019) and many cities, towns and villages capture them to reduce crop damage (Ohdachi et al. 2015), but their economic costs are not included in the entries of the dataset. Moreover, even the national measures, conducted outside of the period and reported on the internet, are not included in the dataset. For example, the mongoose eradication project on Amami-Oshima Island started in 2000 (Watari et al. 2008), but its costs have only been available on the internet since 2014 .

Even if the costs are published on the internet, they are not always listed in the dataset. For example, a document in the database summarising the contents of the budget for biological invasion management, based on "Act on the Prevention of Adverse Ecological Impacts Caused by Designated Invasive Alien Species", included a total of 2,512,000,000 JPY (2012-2017), whereas the amount of costs listed in our dataset (Suppl. material 1: Table S1) was $1,615,000,000$ JPY $(14,766,378$ USD in 2017), meaning $38 \%$ of the total budget was omitted from the dataset of source documents. This gap is due to the difficulties in identifying the target invasive species from the title of each project listed in the source documents, most of which target multiple invasive species.

To access such data, it is necessary to conduct comprehensive and labour-intensive surveys of paper-based materials, as well as individual interviews with countless local government officials. In order to improve this situation, it is important to establish systems that allow the reporting of invasion costs in a widely-available form, such as a platform for indexing and searching administrative data and an open library to enable not only scientists, but also practitioners and decision-makers to easily access the economic costs. 


\section{Importance of including non-English information}

Given the current situation where information from non-English sources has been ignored, becoming a barrier to the advancement of ecological scientific knowledge biodiversity conservation (Amano et al. 2016; Nuñez et al. 2019; Konno et al. 2020), using the InvaCost database will help to ensure that information will be shared more equitably, leading to better global and domestic evaluation of economic costs of invasive species.

Japan is one of the countries with a lower proportion of English speakers (Amano and Sutherland 2013) and, hence, information is more prone to be transmitted/published in Japanese, rather than in English (Konno et al. 2020). Indeed, only one entry was found for Japan in the English database (Diagne et al. 2020b). As a result, the English-based scientific community, has significantly overlooked evidence at least in terms of the economic cost evaluation of invasive species from non-English speaking countries. This study is the first attempt to compile and analyse the economic costs from the scattered data written in Japanese, which could be an important part of the global evaluation. It thus provides valuable information for non-Japanese speaking researchers, as well as practitioners and decision-makers. As the use of English information by local practitioners and decision-makers could usually be limited in non-English countries (Amano and Sutherland 2013; Amano et al. 2016; Angulo et al. 2021), we suggest the need for an increase in the collaboration between scientists and practitioners, to facilitate transfer of knowledge about local biological invasions. Here we show that omitting the non-English information would have resulted in an almost nonexistent evaluation of economic costs for invasive species in Japan and, therefore, partial and biased, in agreement with previous studies (Konno et al. 2020; Angulo et al. 2021). The knowledge bias caused by neglecting the existing non-English information in the economic cost assessment of biological invasions is about to be significantly reduced with the construction of the non-English database used in this study (Angulo et al. 2021). The fact that the available data sources for this Japanese data synthesis were all from the Japanese literature is a typical example that reflects the biased global trend.

\section{Conclusion}

We showed the economic costs of biological invasions in Japan for various taxonomic groups and ecosystems over a period of more than 50 years. These costs mainly focused on humans (as opposed to biodiversity), management (as opposed to damage) and small islands (as opposed to the mainland). This study also showed that the economic costs of biological invasions may be grossly underestimated. Therefore, accepting the amount of economic costs provided here will inevitably lead to an underestimation of the impact of invasive species. To bridge this gap, it is necessary to continue efforts to compile records of economic costs, which will allow us to appropriately balance the impact of invasive species on the one hand and the scale of management measures on the other, hence providing more realistic guidelines for tackling the issue of biological invasions. The findings in this study are not only specific to Japan, but also widely applicable to other countries. 


\section{Acknowledgements}

We would like to thank Gauthier Dobigny for the translation of the abstract into French. YW was funded by the Environment Research and Technology Development Fund (JPMEERF20184004) of the Environmental Restoration and Conservation Agency of Japan. The French National Research Agency (ANR-14-CE02-0021) and BNP-Paribas Foundation Climate Initiative funded the InvaCost project, which allowed the development of the InvaCost database, including the non-English version. The present work was conducted following a workshop funded by the AXA Research Fund Chair of Invasion Biology and is part of the AlienScenario project funded by BiodivERsA and Belmont-Forum Call 2018 on biodiversity scenarios. Funding for the contracts of EA and LBM contracts come from the AXA Research Fund Chair of Invasion Biology. CD was funded by the BiodivERsA-Belmont Forum Project "Alien Scenarios" (BMBF/PT DLR 01LC1807C).

\section{References}

Abe T, Makino S, Okochi I (2008) Why have endemic pollinators declined on the Ogasawara Islands? Biodiversity and Conservation 17: 1465-1473. https://doi.org/10.1007/s10531008-9355-y

Amano T, Gonzalez-Varo JP, Sutherland WJ (2016) Languages are still a major barrier to global science. PLOS Biology 14: e2000933. https://doi.org/10.1371/journal.pbio.2000933

Amano T, Sutherland WJ (2013) Four barriers to the global understanding of biodiversity conservation: wealth, language, geographical location and security. Proceedings of the Royal Society B - Biological Sciences 280(1756): e20122649. https://doi.org/10.1098/rspb.2012.2649

Angulo E, Diagne C, Ballesteros-Mejia L, Ahmed DA, Banerjee AK, Capinha C, Courchamp F, Renault D, Roiz D, Dobigny G, Haubrock PJ, Heringer G, Verbrugge LNH, Golivets M, Nuñez MA, Kirichenko N, Dia CAKM, Xiong W, Adamjy T, Akulov E, DuboscqCarra VG, Kourantidou M, Liu C, Taheri A, Watari Y, Xiong W, Courchamp F (2020) Non-English database version of InvaCost. Figshare. Dataset. https://doi.org/10.6084/ m9.figshare.12928136.v2 [last accessed 30 Sep 2020]

Angulo E, Diagne C, Ballesteros-Mejia L, Adamjy T, Ahmed DA, Akulov E, Banerjee AK, Capinha C, Dia CAKM, Dobigny G, Duboscq-Carra VG, Golivets M, Haubrock PJ, Heringer G, Kirichenko N, Kourantidou M, Liu C, Nuñez MA, Renault D, Roiz D, Taheri A, Verbrugge L, Watari Y, Xiong W, Courchamp F (2021) Non-English languages enrich scientific knowledge: the example of economic costs of biological invasions. Science of the Total Environment 775: 144441. https://doi.org/10.1016/j.scitotenv.2020.144441

Armstrong KF, Ball SL (2005) DNA barcodes for biosecurity: invasive species identification. Philosophical Transactions of the Royal Society B: Biological Sciences 360: 1813-1823. https://doi.org/10.1098/rstb.2005.1713

Auliya M, Altherr S, Ariano-Sanchez D, Baard EH, Brown C, Brown RM, Cantu J-C, Gentile G, Gildenhuys P, Henningheim E, Hintzmann J, Kanari K, Krvavac M, Lettink M, Lip- 
pert J, Luiselli L, Nilson G, Nguyen TQ, Nijman V, Parham JF, Pasachnik SA, Pedrono M, Rauhaus A, Córdova DR, Sanchez M-E, Schepp U, van Schingen M, Schneeweiss N, Segniagbeto GH, Somaweera R, Sy EY, Türkozan O, Vinke S, Vinke T, Vyas R, Williamson S, Ziegler T (2016) Trade in live reptiles, its impact on wild populations, and the role of the European market. Biological Conservation 204: 103-119. https://doi.org/10.1016/j. biocon.2016.05.017

Azumi S, Watari Y, Oka N, Miyashita T (2021) Seasonal and spatial shifts in feral cat predation on native seabirds vs. non-native rats on Mikura Island, Japan. Mammal Research 66: 75-82. https://doi.org/10.1007/s13364-020-00544-5

Bellard C, Cassey P, Blackburn TM (2016) Alien species as a driver of recent extinctions. Biology Letters 12: 20150623. https://doi.org/10.1098/rsbl.2015.0623

Bradshaw CJ, Leroy B, Bellard C, Roiz D, Albert C, Fournier A, Barbet-Massin M, Salles JM, Simard F, Courchamp F (2016) Massive yet grossly underestimated global costs of invasive insects. Nature Communications 7: 12986. https://doi.org/10.1038/ncomms12986

Chiba S (2010) Invasive rats alter assemblage characteristics of land snails in the Ogasawara Islands. Biological Conservation 143: 1558-1563. https://doi.org/10.1016/j.biocon.2010.03.040

Clavero M, Garcia-Berthou E (2005) Invasive species are a leading cause of animal extinctions. Trends in Ecology \& Evolution 20: 110-110. https://doi.org/10.1016/j.tree.2005.01.003

Courchamp F, Chapuis JL, Pascal M (2003) Mammal invaders on islands: impact, control and control impact. Biological Reviews 78: 347-383. https://doi.org/10.1017/ S1464793102006061

Courchamp F, Fournier A, Bellard C, Bertelsmeier C, Bonnaud E, Jeschke JM, Russell JC (2017) Invasion Biology: Specific Problems and Possible Solutions. Trends in Ecology \& Evolution 32: 13-22. https://doi.org/10.1016/j.tree.2016.11.001

Dana ED, Jeschke JM, García-de-Lomas J (2013) Decision tools for managing biological invasions: existing biases and future needs. Oryx 48: 56-63. https://doi.org/10.1017/ S0030605312001263

Diagne C, Catford JA, Essl F, Nuñez MA, Courchamp F (2020a) What are the economic costs of biological invasions? A complex topic requiring international and interdisciplinary expertise. Neobiota 63: 25-37. https://doi.org/10.3897/neobiota.63.55260

Diagne C, Leroy B, Gozlan RE, Vaissière A-C, Assailly C, Nuninger L, Roiz D, Jourdain F, Jarić I, Courchamp F (2020b) InvaCost, a public database of the economic costs of biological invasions worldwide. Scientific Data 7: e277. https://doi.org/10.1038/s41597-020-00586-z

Diagne C, Leroy B, Vaissière A-C, Gozlan RE, Roiz D, Jarić I, Salles J-M, Bradshaw CJA, Courchamp F (2021) High and rising economic costs of biological invasions worldwide. Nature 592: 571-576. https://doi.org/10.1038/s41586-021-03405-6

Ecological Society of Japan (2002) Handbook of Alien Species in Japan. Chijinshokan, Tokyo, 390 pp. [in Japanese]

Fukasawa K, Hashimoto T, Tatara M, Abe S (2013a) Reconstruction and prediction of invasive mongoose population dynamics from history of introduction and management: a Bayesian state-space modelling approach. Journal of Applied Ecology 50: 469-478. https://doi. org/10.1111/1365-2664.12058 
Fukasawa K, Miyashita T, Hashimoto T, Tatara M, Abe S (2013b) Differential population responses of native and alien rodents to an invasive predator, habitat alteration and plant masting. Proceedings of the Royal Society B - Biological Sciences 280(1773): 20132075. https://doi.org/10.1098/rspb.2013.2075

Glen AS, Hoshino K (2020) Social and logistical challenges in managing invasive predators: insights from islands in Japan and New Zealand. Pacific Conservation Biology 26: 344-352. https://doi.org/10.1071/PC19030

Global Invasive Species Database (2020) Global Invasive Species Database, Japan. http://www. iucngisd.org/gisd/ [last accessed 27 Sep 2020]

Higuchi H, Primack RB (2009) Conservation and management of biodiversity in Japan: An introduction. Biological Conservation 142: 1881-1883. https://doi.org/10.1016/j.biocon.2009.03.011

International Monetary Fund (2018) World Economic and Financial Surveys World Economic Outlook Database. https:/www.imf.org/external/pubs/ft/weo/2018/02/weodata/index. aspx [last accessed 3 Sep 2020]

Jackson T (2015) Addressing the economic costs of invasive alien species: some methodological and empirical issues. International Journal of Sustainable Society 7(3): 221-240. https:// doi.org/10.1504/IJSSOC.2015.071303

Japan Meteorological Agency (2016) General Information on Climate of Japan. https:/www. data.jma.go.jp/gmd/cpd/longfcst/en/tourist.html [last accessed 31 Aug 2020] [in Japanese]

JUDGIT! (2019) JUDGIT!. https://judgit.net/ [last accessed 19 January 2021] [in Japanese]

Kagoshima Prefecture (2019) The overview of Amami Islands. https://www.pref.kagoshima. jp/aq01/chiiki/oshima/chiiki/zeniki/gaikyou/h30amamigaikyou.html [last accessed 12 March 2020] [in Japanese]

Karube H (2019) Crisis of endemic insects in the Ogasawara Islands: Urgent need for in-situ and ex-situ conservation. Shinrin Kagaku. 87: 15-18. [in Japanese]

Kettunen M, Genovesi P, Gollasch S, Pagad S, Starfinger U, ten Brink P, Shine C (2008) Technical support to EU strategy on invasive species (IAS) - Assessment of the impacts of IAS in Europe and the EU (final module report for the European Commission). Institute for European Environmental Policy (IEEP), Brussels, 44 pp.

Kiritani K (1998) Exotic insects in Japan. Entomological science 1: 291-298.

Kitade T, Naruse Y (2020) Crossing the red line: Japan's exotic pet trade. TRAFFIC, Japan Office, Tokyo, 64 pp.

Kobayashi S, Kinjo T, Kuroda Y, Kinjo M, Okawara Y, Izawa M, Onuma M, Haga A, Nakaya Y, Nagamine T (2019) Predation on endangered species by cats in the northern forests of Okinawa-Jima Island, Japan. Mammal Study 45: 63. https://doi.org/10.3106/ms2019-0017

Komine H, Takeshita K, Abe S, Ishikawa T, Kimura M, Hashimoto T, Kitaura K, Morosawa T, Seki K, Kaji K (2016) Relationships between capture-site characteristics and capture levels of the invasive mongoose on Amami-Oshima Island, Japan. Biological Invasions 18: 487-495. https://doi.org/10.1007/s10530-015-1021-1

Konno K, Akasaka M, Koshida C, Katayama N, Osada N, Spake R, Amano T (2020) Ignoring non-English-language studies may bias ecological meta-analyses. Ecology and Evolution 10(13): 6373-6384. https://doi.org/10.1002/ece3.6368 
Kourantidou M, Cuthbert RN, Haubrock PJ, Novoa A, Taylor NG, Leroy B, Capinha C, Renault D, Angulo E, Diagne C, Courchamp F (2021) Economic costs of invasive alien species in the Mediterranean basin. In: Zenni RD, McDermott S, García-Berthou E, Essl F (Eds) The economic costs of biological invasions around the world. NeoBiota 67: 427-458. https://doi.org/10.3897/neobiota.67.58926

Koyama J, Kakinohana H, Miyatake T (2004) Eradication of the melon fly, Bactrocera cucurbitae, in Japan: importance of behavior, ecology, genetics, and evolution. Annual Review of Entomology 49: 331-349. https://doi.org/10.1146/annurev.ento.49.061802.123224

Kueffer C, Pyšek P, Richardson DM (2013) Integrative invasion science: model systems, multi-site studies, focused meta-analysis and invasion syndromes. New Phytology 200(3): 615-633. https://doi.org/10.1111/nph.12415

Leroy B, Kramer AM, Vaissière A-C, Courchamp F, Diagne C (2020) Analysing global economic costs of invasive alien species with the invacost $\mathrm{R}$ package. BioRXiv. https://doi. org/10.1101/2020.12.10.419432

Maeda T, Nakashita R, Shionosaki K, Yamada F, Watari Y (2019) Predation on endangered species by human-subsidized domestic cats on Tokunoshima Island. Scientific Reports 9: 16200. https://doi.org/10.1038/s41598-019-52472-3

Ministry of Agriculture, Forestry and Fisheries (2013) Crop damage statistics by disaster types (results of the emergency survey): Damages to the rice plants caused by brown planthopper. https://www.e-stat.go.jp/stat-search/database?page=1 \&toukei=00500215\&tst at $=000001013427$ [last accessed 31 Aug 2020] [in Japanese]

Ministry of Agriculture, Forestry and Fisheries (2020) Damages to agricultural production. https://www.maff.go.jp/j/seisan/tyozyu/higai/hogai_zyoukyou/index.html [last accessed 27 Sep 2020] [in Japanese]

Mito T, Uesugi T (2004) Invasive alien species in Japan: The status quo and the new regulation for prevention of their adverse effects. Global Environmental Research 8: 171-191.

Mizutani T, Goka K (2010) Japan's Invasive Alien Species Act. Applied Entomology and Zoology 45: 65-69. https://doi.org/10.1303/aez.2010.65

Nghiem LTP, Soliman T, Yeo DC, Tan HT, Evans TA, Mumford JD, Keller RP, Baker RH, Corlett RT, Carrasco LR (2013) Economic and environmental impacts of harmful non-indigenous species in southeast Asia. PLoS ONE 8: e71255. https://doi.org/10.1371/journal.pone.0071255

Nuñez MA, Barlow J, Cadotte M, Lucas K, Newton E, Pettorelle N, Stehens PA (2019) Assessing the uneven global distribution of redership, submissions and publications in applied ecology: Obvious problems without obvious solutions. Journal of Applied Ecology 56: 4-9. https://doi.org/10.1111/1365-2664.13319

Nuñez MA, Pauchard A (2010) Biological invasions in developing and developed countries: does one model fit all? Biological Invasions 12: 707-714. https://doi.org/10.1007/s10530009-9517-1

Nunes PALD, van den Bergh JCM (2001) Economic valuation of biodiversity: sense or nonsense? Ecological Economics 39: 203-222. https://doi.org/10.1016/S0921-8009(01)00233-6

Ohdachi SD, Ishibashi Y, Iwasa MA, Fukui D, Saitoh T (2015) The wild mammals of Japan. Shoukado Book Sellers and the Mammal Society of Japan, Kyoto, 506 pp. 
Okabe K, Watari Y, Yano Y, Maeda K, Goka K (2019) Wildlife management considering tickborne diseases, particularly emerging infectious diseases. Japanese Journal of Conservation Ecology 24: 109-124. [in Japanese with English abstract]

Pimentel D, Zuniga R, Monison D (2005) Update on the environmental and economic costs associated with alien-invasive species in the United States. Ecological Economics 52: 273-288. https://doi.org/10.1016/j.ecolecon.2004.10.002

Rose DC, Sutherland WJ, Amano T, Gonzalez-Varo JP, Robertson RJ, Simmons BI, Wauchope HS, Kovacs E, Duran AP, Vadrot ABM, Wu W, Dias MP, Di Fonzo MMI, Ivory S, Norris L, Nunes MH, Nyumba TO, Steiner N, Vickery J, Mukherjee N (2018) The major barriers to evidence-informed conservation policy and possible solutions. Conservation Letters 11(5): e12564. https://doi.org/10.1111/conl.12564

Sato N (2019) Recent control of invasive alien animals in the Bonin Islands. Global Environmental Research 23: 9-19.

Shionosaki K, Yamada F, Ishikawa T, Shibata S (2015) Feral cat diet and predation on endangered endemic mammals on a biodiversity hot spot (Amami-Ohshima Island, Japan). Wildlife Research 42: 343-352. https://doi.org/10.1071/WR14161

Sugimura K, Ishida K, Abe S, Nagai Y, Watari Y, Tatara M, Takashi M, Hashimoto T, Yamada F (2014) Monitoring the effects of forest clear-cutting and mongoose Herpestes auropunctatus invasion on wildlife diversity on Amami Island, Japan. Oryx 48: 241-249. https://doi. org/10.1017/S0030605312001639

Suzuki T, Ikeda T (2019) Challenges in managing invasive raccoons in Japan. Wildlife Research 46: 476-483. https://doi.org/10.1071/WR18

Tokyo Metropolitan Government (2016) Management plan for invasive Reeves's muntjac in Tokyo. https://www.kankyo.metro.tokyo.lg.jp/nature/animals_plants/kyon.files/kyon_ plan201603.pdf [last accessed 12 Sep 2020] [in Japanese]

UNESCO World Heritage Centre (2012) Ogasawara Islands. https://whc.unesco.org/en/ list/1362 [last accessed 31 Aug 2020]

UNESCO World Heritage Centre (2016) Amami-Oshima Island, Tokunoshima Island, the northern part of Okinawa Island and Iriomote Island. https://whc.unesco.org/en/tentativelists/6160 [last accessed 31 Aug 2020]

Watari Y (2011) Toward recovery: mongoose management and the Japanese herpetofauna. Japanese Journal of Herpetology 2011: 137-147. [in Japanese with English abstract]

Watari Y, Nishijima S, Fukasawa M, Yamada F, Abe S, Miyashita T (2013) Evaluating the "recovery level" of endangered species without prior information before alien invasion. Ecology and Evolution 3: 4711-4721. https://doi.org/10.1002/ece3.863

Watari Y, Takatsuki S, Miyashita T (2008) Effects of exotic mongoose (Herpestes javanicus) on the native fauna of Amami-Oshima Island, southern Japan, estimated by distribution patterns along the historical gradient of mongoose invasion. Biological Invasions 10: 7-17. https://doi.org/10.1007/s10530-007-9100-6

World Trade Statistical Review (2019) World Trade Organization. https:/www.wto.org/english/res_e/statis_e/wts2019_e/wts19_toc_e.htm [last accessed 31 Aug 2020]

Yagihashi T, Seki S-I, Nakaya T, Nakata K, Kotaka N (2021) Eradication of the mongoose is crucial for the conservation of three endemic bird species in Yambaru, Okinawa Island, Japan. Biological Invasions. [12 pp.] https://doi.org/10.1007/s10530-021-02503-w 


\section{Supplementary material I}

Table S1. Dataset of the economic costs of biological invasion in Japan

Authors: Yuya Watari, Hirotaka Komine, Elena Angulo, Christophe Diagne, Liliana Ballesteros-Mejia, Franck Courchamp

Data type: database

Explanation note: The dataset of the economic costs of biological invasion in Japan extracted from the InvaCost_v3.0 (openly available at https://doi.org/10.6084/ $\mathrm{m} 9$.figshare.12668570) and the additional search in this study.

Copyright notice: This dataset is made available under the Open Database License (http://opendatacommons.org/licenses/odbl/1.0/). The Open Database License $(\mathrm{ODbL})$ is a license agreement intended to allow users to freely share, modify, and use this Dataset while maintaining this same freedom for others, provided that the original source and author(s) are credited.

Link: https://doi.org/10.3897/neobiota.67.59186.suppl1

\section{Supplementary material 2}

\section{Definition of the categorisation of economic costs}

Authors: Yuya Watari, Hirotaka Komine, Elena Angulo, Christophe Diagne, Liliana Ballesteros-Mejia, Franck Courchamp

Data type: adittional data

Explanation note: Damage_Biodiversity and Damage_Human represent damage caused by biological invasions to biodiversity and human livelihood, respectively. Management_Biodiversity and Management_Human represent management for biodiversity and human livelihood, respectively. Categories in each cost entry are shown in Suppl. material 1: Table S1.

Copyright notice: This dataset is made available under the Open Database License (http://opendatacommons.org/licenses/odbl/1.0/). The Open Database License $(\mathrm{ODbL})$ is a license agreement intended to allow users to freely share, modify, and use this Dataset while maintaining this same freedom for others, provided that the original source and author(s) are credited.

Link: https://doi.org/10.3897/neobiota.67.59186.suppl2 